America. There are short interesting accounts of the work of Maury, Wyville Thomson, Murray, Hensen, Chun, the Prince of Monaco, A. Agassiz and many others.

Part 2 consists of seven chapters on chemistry and physics, one being on deposits at the bottom of the sea and three on sea water in motion. The leading idea in these chapters is that "the seas, all together, constitute a great dynamical system with an intricate and world-wide mechanism for mixing everything soluble that comes into it". Of course, physical and dynamical processes are not considered in any detail. Many results are quoted from the recent writings of H. U. Sverdrup, and the whole appears to be up to date and accurate. These chapters have many biological references and prepare the way for dealing with conditions under which marine plants and animals live.

Part 3 consists of seven chapters on life in the sea which are packed with information. There are numerous references in footnotes which pay a handsome tribute to Murray and Hjort's "The Depths of the Ocean", now unfortunately out of print. The author states that "life in the sea cannot be treated adequately in a few chapters : volumes are required", and the truth of this is constantly in the mind of the reader; but the tension is eased by the inclusion of a useful summary at the end of each chapter. The author depends, to some extent, upon a historical approach to unfold the theme of each chapter. $\mathrm{He}$ takes the reader back to the benthos and nekton of Hreckel, and is obviously impressed throughout with similar classifications of marine animals according to their mode of life. One chapter deals briefly with algæ, diatoms and dinoflagellates as pasturage of the sea, with a passing reference to the growing importance attached to the study of marine bacteria. There are two chapters on plankton. This is described by reviewing members according to the groups or phyla to which they belong. Then follow chapters on the benthos and nekton, the latter concentrating upon fishes with a special paragraph headed "Useful Fishes". There are also interesting references to the methods of capturing fish which fall in line with the equally useful descriptions in earlier chapters of gear used for obtaining plankton and bottom fauna. To complete the survey, turtles, seafowl, sea otters, sea lions, sea cows and whales are included. Altogether, a full programme which may leave the reader a little breathless, but which ought to stimulate his interest in "This Great and Wide Sea".

\section{SOIL FERTILITY}

\section{Chemicals, Humus and the Soil}

A Simple Presentation of Contemporary Knowledge and Opinions about Fertilizers, Manures and Soil Fertility. By Donald P. Hopkins. Pp. $278+5$ plates. (London: Faber and Faber, Ltd., 1945.) 12s. $6 d$. net.

A FEATURE of the present-day attitude to A agriculture is the increasing concern about soil fertility. Formerly this was confined to a limited number of specialists; but the impact of two world wars and the resulting shortages made all of us think about food, and awakened an interest about soil problems in the more reflective. There is an increasing literature about these matters both from the scientific and economic points of view, and Mr. Hopkins' very readable book deals with a section of this field which has perhaps received wider publicity than any other. The late Sir Albert Howard and his followers have for many years advocated certain methods of soil management in which humus maintenance by means of composts plays the chief part, and chemical fertilizers are entirely excluded. It is claimed that crops grown on compost are healthier and of better feeding value than those grown with chemicals and, further, the continued use of inorganic salts damages the soil population. The full thesis of the compost school has never been accepted by soil scientists; but the case has been put forward with such energy and conviction that there have been many converts, while others are left wondering if there may not be another side to the story. It is here that Mr. Hopkins' book fills a real need. Its purpose is to set out for non-specialist readers the evidence for and against fertilizers as fairly as possible. The author is a chemist engaged in the manufacture of fertilizers, so complete detachment can scarcely be expected; nevertheless his case is presented with a skill and moderation not always found in the rival school.

The book is in two parts. The first deals with the broad facts of plant nutrition, and shows that, unaided, most soils are unable to supply sufficient readily available nutrients for high production. Innumerable field trials have proved that fertilizers rightly used can supply this nutrient deficiency. A discussion of the various means of enriching the soil in organic matter follows, and estimates are given to show that all the organic wastes in sight are insufficient to meet the nitrogen requirements of an intensive arable agriculture. The rational procedure, which has the backing of almost all scientific opinion, is to use as much organic material as possible for its humic value and supplement its nutritional content with chemical fertilizers. In the second part of the book the author examines the charges that fertilizers inhibit mycorrhizal development, and exterminate earthworms and bacteria. $\mathrm{He}$ concludes that these charges are not proved; although gross misuse of fertilizers, such as the rendering of soil excessively acid by continued heavy doses of ammonium salts, may upset the soil populations. Passing on to the argument that fertilizers cause plant disease, the author points out that there were devastating outbreaks of disease before artificials were in general use. Once again wrong use of fertilizers, unbalanced nitrogen applications, may increase susceptibility to certain diseases. It is on the grounds of the alleged improved food value of produce grown with humic fertilizers that the compost school have gained many adherents. Even here the evidence from official research stations appears to be negative. Experiments that gave positive indications have, strangely enough, not been extensively repeated; while evidence based on the state of health of widely separated communities consuming different diets is not convincing.

Several topics not directly in the line of argument are included ; for example, a concise and well-informed chapter on the fertilizers themselves.

Mr. Hopkins' book is written in a much less formal style than the scientific text-book, and he goes to some trouble to dissect faulty arguments. Apart from the public to whom it is addressed, many students who have mastered the elements of their subject might read this book with considerable profit. 